\title{
Composition and Molecular Weight Distribution of Albumin and Globulin Protein Isolates from Durum Wheat Genotypes
}

\author{
Daniel Hailegiorgis', Fikru Mekonnen1, Faris Hailu², Chong Ae Lee3, Song Joong Yun4* \\ ${ }^{1}$ Department of Plant Science, Wollo University, Dessie, Ethiopia \\ ${ }^{2}$ Department of Biology, Wollo University, Dessie, Ethiopia \\ ${ }^{3}$ Institute of Agricultural and Life Sciences, Jeonbuk National University, Jeonju, Republic of Korea \\ ${ }^{4}$ Department of Crop Science and Biotechnology, Jeonbuk National University, Jeonju, Republic of Korea \\ Email: *sjyun@jbnu.ac.kr
}

How to cite this paper: Hailegiorgis, D., Mekonnen, F., Hailu, F., Lee, C.A. and Yun, S.J. (2020) Composition and Molecular Weight Distribution of Albumin and Globulin Protein Isolates from Durum Wheat Genotypes. American Journal of Plant Sciences, 11, 137-147.

https://doi.org/10.4236/ajps.2020.112011

Received: December 27, 2018

Accepted: February 14, 2020

Published: February 17, 2020

Copyright ( 2020 by author(s) and Scientific Research Publishing Inc. This work is licensed under the Creative Commons Attribution International License (CC BY 4.0).

http://creativecommons.org/licenses/by/4.0/

\begin{abstract}
This paper attempts to evaluate the banding patterns of non-gluten protein isolates from the grain of durum wheat varieties. Under reduced condition, polyacrylamide-gel electrophoresis has revealed a number of different sized albumin and globulin protein bands. The electrophoretic pattern of globulin showed more polymorphisms than that of albumin. High polymorphism, both in band intensity and occurrence, was observed between $15 \mathrm{kDa}$ and 35 $\mathrm{kDa}$. Most of the protein bands were scored in the range of $10 \mathrm{kDa}$ and 85 $\mathrm{kDa}$ in the two protein fractions. At a cutoff point 2.5 , cluster analysis based on the SDS-PAGE of globulin proteins classified the durum wheat varieties into three major family groups. Generally, the experiment showed the suitability and usefulness of globulin protein fractions as a genetic marker in discriminating durum wheat genotypes.
\end{abstract}

\section{Keywords}

Albumin, Durum Wheat, Globulin, Polymorphism, Seed Protein

\section{Introduction}

Seed proteins are one of the most abundant and highly diverse class of biomolecules. The gliadin and glutenin proteins are the most commonly used protein markers for the identification of germplasms in genetic diversity analysis. The reason for this is that the gluten proteins are highly diverse and they are found abundantly [1]. The use of electrophoretic patterns of albumin and globulins for genetic diversity analysis are less common and barely used. 
Albumin and globulin proteins, also known as Leukosin and Edestin, respectively, represent $10 \%$ to $30 \%$ of total flour protein [2] [3]. These proteins are found mainly in the embryo and seed aleurone layer [4]. Albumins are believed to have roles as nutrient reserve for the germinating embryo, defense to insects and fungal pathogens, and influence on grain hardness [5] [6]. In addition, they also act as enzymes and enzyme inhibitors [7].

Apart from their structural, protective and metabolic functions some high molecular weight albumins and certain globulin proteins are believed to have storage function too [8] [9].

From nutrition point of view, albumin and globulin proteins are considered to be best in terms of their amino acid compositions. These protein fractions have higher lysine and methionine contents as compared to the gliadin and glutenin proteins [10]. The most common albumins and globulin proteins are $\alpha$-amylase/ trypsin, serpins and purothionins [5].

Evaluation of cultivars using protein markers has a potential to give more reasonable information. Many of the seed proteins constitute a multigene family that are transmitted from generation to generation. Therefore, they are used as useful indicators in varietal identification and as a breeding tool to select plants with desirable trait [4].

The main objective of this research was to study the composition and electrophoretic pattern of non-gluten protein fractions from durum wheat.

\section{Materials and Methods}

\subsection{Experimental Materials}

Twenty improved durum wheat varieties of Ethiopian origin were included in the present study. Their local names, pedigrees, origin and adaptation areas are given in Table 1. The seed samples grown in Ethiopia in 2017 were used in this experiment. All analyses were conducted in the same year in the Department of Crop Science and Biotechnology, Jeonbuk National University, Jeonju, South Korea [11].

\subsection{Protein Fractionation}

One hundred milligrams of finely ground wheat flour was used to sequentially extract the four major protein fractions by the Osborne procedure [12]. Albumin proteins were extracted by deionized water with intermittent vortexing every 10 min for half an hour. The supernatant obtained following centrifugation at 2000 rpm for 5 min (albumin extract) was saved for further analysis. The procedure has been repeated twice to remove all the albumin fractions before proceeding to the next step.

The pellet from the final albumin extraction was used to extract globulin fraction. The extraction was conducted using $0.5 \mathrm{~N} \mathrm{NaCl}$ for 30 min with intermittent vortexing every $10 \mathrm{~min}$. In similar fashion, the supernatant obtained following centrifugation at $2000 \mathrm{rpm}$ for $5 \mathrm{~min}$ (globulin extract) was kept in 
Table 1. List of durum wheat varieties, source of seed, pedigree, year of release and adaptation.

\begin{tabular}{|c|c|c|c|c|}
\hline Variety name & Source of seed & Pedigrees and/selection history & $\begin{array}{l}\text { Year of } \\
\text { release }\end{array}$ & $\begin{array}{c}\text { Adaptation } \\
\text { area (altitude) }\end{array}$ \\
\hline Yerer & CIMMYT & CHEN/TEZ/GVILI/C11 & 2002 & $1800-2700$ \\
\hline Hitosa & CIMMYT/Ethiopia & CHEN/ALTAR84 ... CDS-97-B00265. IQX... 6DZR & 2009 & $1800-2650$ \\
\hline Denbi & CIMMYT/Ethiopia & AJAIAIBAUSHEN ... CSS98IY00025-0MXI-3QK-4DZR & 2009 & $1800-2650$ \\
\hline Mangudo & CGIAR germplasm & MRF1/STJ2/3/1718/BT24//KARIM & 2012 & $1900-2700$ \\
\hline Kilinto & CIMMYT/Ethiopia & ILLUMILO/INRAT9/BHA/3/HORA/4/CIT 71/JORI & 1994 & $1600-2700$ \\
\hline Mukiye & & STJ3 //BCR /LKS4/3/TER-3 & 2012 & $1900-2700$ \\
\hline Candateutuba & CIMMYT/Ethiopia & Omruf1/Stojocri2/3/1718/BeadWheat24//Kari m & 2015 & $1800-2750$ \\
\hline Cocorit-71 & CIMMYT/Ethiopia & RAE/4*TC60//STW63/3/AA“s”DZ27617-18-64-OM & 1976 & $2200-2500$ \\
\hline Tob-66 (Arsi Robe) & CIMMYT/Ethiopia & REICHENBACHII/LD357//DUCK/YEL & 1996 & $2000-2500$ \\
\hline Assesa & CIMMYT/Ethiopia & $\begin{array}{c}\mathrm{CHO} / \mathrm{TARUS} / / \mathrm{YAV} / 3 / \mathrm{FG} / \mathrm{CRA} / 5 / \mathrm{FG} / \mathrm{DOM} / 6 / \mathrm{HUI} \text { or } \\
\mathrm{CHORLITO/YAVAROS//FREE-GALLIPOLI/3/} \\
\text { FREE-GALLIPOLI/CANADIAN-RED/4/ } \\
\text { FREE-GALLIPOLI/DON-PEDRO/5/HUITLE }\end{array}$ & 1997 & $1680-2400$ \\
\hline Bichena & CIMMYT/Ethiopia & IM/CIT 71 & 1995 & $900-2600$ \\
\hline Boohai & CIMMYT/Ethiopia & $\begin{array}{l}\text { COO"S"/CII or COOT(SIB)/CANDEAL-II or } \\
\text { COCORIT71/CANDEAL-II }\end{array}$ & 1982 & $1800-2500$ \\
\hline Foka & CIMMYT/Ethiopia & COCORIT71/CANDEAL-II & 1993 & $1800-2700$ \\
\hline Gerardo (Jorro) & CIMMYT & VZ466/61-130xLdsxGII“s”CM9605 & 1976 & $1800-2500$ \\
\hline Ginchi & CIMMYT/Ethiopia & BOOHAI/ULNV-DZ1050 & 2000 & $2000-2300$ \\
\hline Quamy & CIMMYT/Ethiopia & $\begin{array}{l}\text { ADS//PGO/CANDEALII/7/JO“S”/CR"S"//GS“S”/SBA81/3/F } \\
\text { G“S"/4/FG"S"/CR“S”/5/F“S”DOM“S"/6/HUI"S"CD75533-A }\end{array}$ & 1996 & $1600-2200$ \\
\hline Robe & CIMMYT/Ethiopia & $\begin{array}{l}\text { Hora/cit“s”//Jo“s”/GS“s”/3//4/Hora } \\
\text { Respinnegro//CM9908/3/Rahum or } \\
\text { ACONCHI-89/3/MAGHREBI-72/RUFFOUS// } \\
\text { ALGERIAN-86/RUFINA/4/LABUD-27 }\end{array}$ & 1999 & $2000-2500$ \\
\hline Ude & $\begin{array}{l}\text { CIMMYT/CGIAR } \\
\text { germplasm }\end{array}$ & CHEN/ALTAR84//J069 & 2002 & $1800-2700$ \\
\hline LD-357 & CIMMYT/Ethiopia & LD308/NUGGET & 1979 & $2200-2500$ \\
\hline Werer & CIMMYT/Ethiopia & No information & 2009 & $450-1200$ \\
\hline
\end{tabular}

Source: Jemanesh K. [13], Crop variety register Issue $1-12$ and http://wheatatlas.org/ website CGIAR = Consultative Group for International Agricultural Research; CIMMYT = International Maize and Wheat Improvement Centre.

refrigerator for further analysis. Extraction was repeated twice to avoid carry over (cross-contamination) of globulin fraction to the subsequent steps. The centrifugate was washed with distilled water to reduce the effect of the salt in the extraction of other proteins in the subsequent steps.

\subsection{SDS-PAGE Analysis}

Protein fractions were analyzed under reduced conditions (in the presence of beta-mercaptoethanol) using discontinuous SDS-PAGE [14]. The electrophoresis was conducted in $12 \%$ separating gel and and $6 \%$ stalking gel. Separation of pro- 
tein bands was conducted at a constant voltage of $200 \mathrm{~V}$ until bromophenol blue passes the stacking gel and then raised gradually to $500 \mathrm{~V}$. Following electrophoresis, the gels were stained with $0.2 \%(\mathrm{w} / \mathrm{v}) \mathrm{CBB}$ in $45 \%(\mathrm{w} / \mathrm{v})$ methanol and $10 \%(\mathrm{w} / \mathrm{v})$ acetic acid under constant agitation. Destaining was conducted in $45 \%$ methanol and $10 \%$ acetic acid solution.

The acrylamide solution was made from $30 \mathrm{~g}$ acrylamide monomer and $0.8 \mathrm{~g}$ bisacrylamide in distilled water. The resolving gel buffer was composed of $36.6 \mathrm{~g}$ Tris base and $40 \mathrm{~mL}$ of $0.1 \mathrm{M} \mathrm{HCl}$ and the $\mathrm{pH}$ was adjusted to 8.8. Stacking gel buffer composition was $6.06 \mathrm{~g}$ Tris base dissolved in $40 \mathrm{~mL}$ of distilled water. The $\mathrm{pH}$ of the stalking gel adjusted to 6.8 using weak acid.

Molecular weights of the protein bands (polypeptides) were estimated by using Thermo Scientific PageRuler Plus prestained Protein Ladder having a mixture of nine blue, orange, and green dyed proteins $(10-250 \mathrm{kDa})$.

The protein bands on the destained gel were quantitated using AlphaEaseFC 4.0 software (Alpha Innotech Corporation, San Leandro, CA).

\subsection{Determination of Protein Content}

The extracted samples were mixed with a buffer containing $2 \mathrm{mM} \mathrm{DTT}, 0.1 \%$ Triton X-100 and $63 \mathrm{mM}$ Tris- $\mathrm{HCl}$ (pH 6.8). The reagent solution was prepared by mixing the Bradford reagent (100 $\mathrm{mg}$ of CBB G-250 in $50 \mathrm{ml}$ of $95 \%$ ethanol) with $100 \mathrm{ml}$ of $85 \%$ ortho-phosphoric on a magnetic stirrer. The resulting solution was filtered through filter paper (Whatman) and stored in a dark bottle at $4^{\circ} \mathrm{C}$. Standard curve was plotted by using seven concentrations [0 (blank), 0.2, $0.4,0.6,0.8,1,1.2 \mathrm{mg} / \mathrm{ml}$ ) of bovine serum albumin (BSA) against a blank (deionized water). Absorbance was measured from $1 \mathrm{ml}$ of the reaction solution at $595 \mathrm{~nm}$ after $3 \mathrm{~min}$ of incubation at room temperature. The absorbance of blank was subtracted from standards concentrations to obtain the actual concentration of the sample. Quantification of proteins was performed in triplicate. The spectrophotometric absorbance was read on Biotek Synergy 2 Micro-plate reader instrument using a Gen5 computer software program.

The absorbance reading was converted to protein concentration using a standard curve established with BSA dissolved in lysis buffer. The protein content was calculated using the following equation:

$$
\operatorname{Protein}(\%, w / w)=C V D / M \times 100
$$

where $C$ is protein concentration $(\mathrm{mg} / \mathrm{ml})$ obtained from standard curve.

$V$ is volume (ml) of the lysis buffer used to resuspend the biomass.

$D$ is the dilution factor.

$M$ is the amount of biomass (mg).

\subsection{Micro-Kjeldahl Method}

The total protein content of the durum wheat varieties was estimated by micro-Kjeldahl method using nitrogen analyzer by taking 5.7 as a conversion factor. Three replicate measurements were taken to estimate error variance. 


\subsection{SDS-Sedimentation Test}

SDS-sedimentation volume was measured following Axford method [15].

\subsection{Statistical Analysis}

All analyses were replicated three times and means were compared by Fisher's least significant differences (LSD) at $\mathrm{P}<0.05$ and $\mathrm{P}<0.01$ using SAS statistical package [16]. Dendrogram was constructed from the electrophoretic data using Xlstat software.

\section{Results and Discussion}

\subsection{Distribution of Protein Fractions}

The water soluble albumin and dilute salt soluble globulin proteins were separated and quantified. It is found that variety Robe had the highest albumin content (19.35\%) while Boohai (15.34\%) lowest. Albumin concentrations in wheat grain ranging from $18 \%$ to $21 \%$ have been reported elsewhere [17].

In globulins, the highest amount was recorded for varieties Cocorit-71 (10.70\%), while for Gerardo (6.07\%) the lowest. The albumin and globulin content of most common wheat proteins is reported to be in the range of $20 \%-25 \%$ [2]. Our findings also confirmed similar results with an average albumin and globulin content of $27 \%$.

The data presented in Table 2 showed that, the content of total protein is statistically significant $(\mathrm{P}<0.01)$ suggesting the presence of considerable variation in protein content among durum wheat varieties. In the present study, protein content in grain of durum wheat ranged from $8.08 \%$ (Candate-Utuba) to $14.28 \%$ (Boohai and Tob-66). Other previous research findings reported grain protein content in the range of 7 to 12.5 among 15 Ethiopian durum wheat varieties [18]. The protein content of grain is affected mainly by genetic factor. However, environment and many other factors may also play a great role in determining the protein content of the crop [19] [20].

The experimental results based on the absorbance reading revealed gliadin proteins (also known as large monomeric gluten proteins), to be predominant protein fractions (51.47\%). Albumins and globulins accounted only for $27 \%$ of the total protein. The ratio of gliadin to glutenin proteins was close to 4:1.

The correlation between total protein content and individual protein fractions was evaluated statistically (results not shown here). There was no significant correlation among the individual protein fractions and the total protein content. Contrary to the present finding, there are reports of strong relationship between albumin-globulin fractions and total protein content [21]. Sedimentation volume test had some positive correlation with protein content and this shows that the volume of sediment is a good indicator of protein content.

\subsection{SDS-PAGE Pattern}

The albumin-globulin proteins were separated and identified by electrophoresis. 
Table 2. Distribution of individual protein fractions according to their solubility in durum wheat varieties.

\begin{tabular}{|c|c|c|c|c|c|c|c|}
\hline \multirow{3}{*}{ Varieties } & \multirow{3}{*}{$\begin{array}{l}\text { Total Protein } \\
\text { (mg/100mg } \\
\text { flour) }\end{array}$} & \multicolumn{2}{|c|}{$\begin{array}{l}\text { Soluble (non-gluten,) } \\
\text { proteins }\end{array}$} & \multirow{2}{*}{$\begin{array}{c}\text { Large } \\
\text { monomeric } \\
\text { proteins } \\
\text { (Gliadin) }\end{array}$} & \multirow{2}{*}{$\begin{array}{l}\text { Soluble and } \\
\text { insoluble } \\
\text { Glutenin }\end{array}$} & \multirow{2}{*}{$\begin{array}{l}\text { Ratio of } \\
\text { gliadin to } \\
\text { glutenin } \\
\text { proteins }\end{array}$} & \multirow{2}{*}{$\begin{array}{c}\text { SDS } \\
\text { Sedimentation } \\
(\mathrm{ml})\end{array}$} \\
\hline & & Albumin & Globulin & & & & \\
\hline & & $(w / w)$ & $(w / w)$ & $(w / w)$ & $(w / w)$ & $\%$ ratio & \\
\hline Werer & $12.45 \pm 0.085^{\mathrm{de}}$ & 19.09 & 7.40 & 54.44 & 15.29 & 3.56 & $5.5 \pm 0.23^{\mathrm{ef}}$ \\
\hline Yerer & $11.87 \pm 0.006^{\mathrm{f}}$ & 17.53 & 6.26 & 45.68 & 18.23 & 2.51 & $4.3 \pm 0.42^{\mathrm{i}}$ \\
\hline Asasa & $10.37 \pm 0.025^{\mathrm{h}}$ & 17.12 & 7.10 & 54.76 & 19.47 & 2.81 & $4.6 \pm 0.20^{\mathrm{i}}$ \\
\hline Hitosa & $10.25 \pm 0.045^{\mathrm{h}}$ & 18.20 & 10.11 & 54.96 & 14.01 & 3.92 & $4.9 \pm 0.42^{\mathrm{h}}$ \\
\hline Candate-utuba & $8.08 \pm 0.000^{j}$ & 17.12 & 10.07 & 51.63 & 17.51 & 2.95 & $3.4 \pm 0.20^{j}$ \\
\hline Ude & $11.21 \pm 0.000^{\mathrm{g}}$ & 17.64 & 7.82 & 49.80 & 16.92 & 2.94 & $5.1 \pm 0.12^{\mathrm{gh}}$ \\
\hline Foka & $13.73 \pm 0.020^{\mathrm{b}}$ & 17.79 & 9.73 & 53.75 & 11.73 & 4.58 & $5.7 \pm 0.12^{\text {efd }}$ \\
\hline Denbi & $12.35 \pm 0.060^{\mathrm{e}}$ & 17.60 & 9.94 & 49.05 & 14.99 & 3.27 & $4.3 \pm 0.36^{\mathrm{i}}$ \\
\hline Mangudo & $8.13 \pm 0.055^{j}$ & 16.01 & 10.08 & 45.39 & 14.21 & 3.19 & $3.7 \pm 0.12^{j}$ \\
\hline Bichena & $13.62 \pm 0.035^{\mathrm{b}}$ & 17.68 & 10.24 & 50.45 & 10.06 & 5.01 & $5.8 \pm 0.06^{\mathrm{cde}}$ \\
\hline Tob-66 & $14.28 \pm 0.012 \mathrm{a}$ & 17.79 & 10.14 & 44.44 & 14.54 & 3.06 & $5.8 \pm 0.25^{\text {cdef }}$ \\
\hline LD 357 & $11.91 \pm 0.045^{\mathrm{f}}$ & 18.05 & 10.14 & 51.30 & 19.67 & 2.61 & $4.5 \pm 0.17^{\mathrm{i}}$ \\
\hline $\begin{array}{l}\text { Ginchi/ } \\
\text { DZ-1050 }\end{array}$ & $12.53 \pm 0.080^{\text {cde }}$ & 18.01 & 9.84 & 54.41 & 11.73 & 4.64 & $6.0 \pm 0.20^{\text {cd }}$ \\
\hline Kilinto & $8.58 \pm 0.035^{\mathrm{i}}$ & 18.23 & 9.73 & 55.61 & 8.16 & 6.81 & $4.2 \pm 0.20^{\mathrm{i}}$ \\
\hline Cocorit 71 & $12.69 \pm 0.075^{c}$ & 18.57 & 10.70 & 55.94 & 13.33 & 4.20 & $6.6 \pm 0.35^{\mathrm{a}}$ \\
\hline Quamy & $13.67 \pm 0.105^{\mathrm{b}}$ & 18.42 & 9.87 & 46.30 & 15.58 & 2.97 & $6.2 \pm 0.20^{\mathrm{ab}}$ \\
\hline Boohai & $14.28 \pm 0.020^{\mathrm{a}}$ & 15.34 & 9.94 & 54.24 & 16.01 & 3.39 & $6.1 \pm 0.12^{\mathrm{bc}}$ \\
\hline Mukiye & $11.75 \pm 0.095^{\mathrm{f}}$ & 18.49 & 10.35 & 45.48 & 6.14 & 7.41 & $3.6 \pm 0.29^{j}$ \\
\hline Robe & $12.56 \pm 0.010^{\mathrm{cd}}$ & 19.35 & 7.76 & 54.44 & 15.16 & 3.59 & $5.5 \pm 0.12^{\mathrm{ef}}$ \\
\hline Gerardo & $12.33 \pm 0.035^{\mathrm{e}}$ & 19.09 & 6.07 & 57.22 & 17.35 & 3.30 & $5.4 \pm 0.12^{\mathrm{gf}}$ \\
\hline Mean & 11.69 & 17.85 & 9.16 & 51.46 & 14.50 & 3.83 & 5.1 \\
\hline $\mathrm{CV}$ & 0.155 & & & & & & 0.18 \\
\hline LSD & 0.2026 & & & & & & 0.3949 \\
\hline
\end{tabular}

$\mathrm{w} / \mathrm{w}$, the proportion of individual protein fractions from total protein expressed in weight to weight basis.

The electrophorograms show the patterns and molecular weight distribution of albumin and globulin proteins (Figures 1-3).

Around 10 to 16 different polypeptides were detected in the globulin fraction. Their molecular weight ranged from 10 to $70 \mathrm{kDa}$. Among the seven prominentglobulin polypeptides identified, five major ones' molecular weight were 15 , $20,35,55$, and $70 \mathrm{kDa}$, respectively (Figure 1 ). These results are consistent with previous research findings [3] [22] which reported globulin polypeptides ranging from 12.4 to $76.4 \mathrm{kDa}$.

In the globulin proteins, high polymorphism in both band intensity and occurrence was observed in those with molecular weights between 15 and $35 \mathrm{kDa}$. The presence of polymorphism in this molecular weight range suggests that 


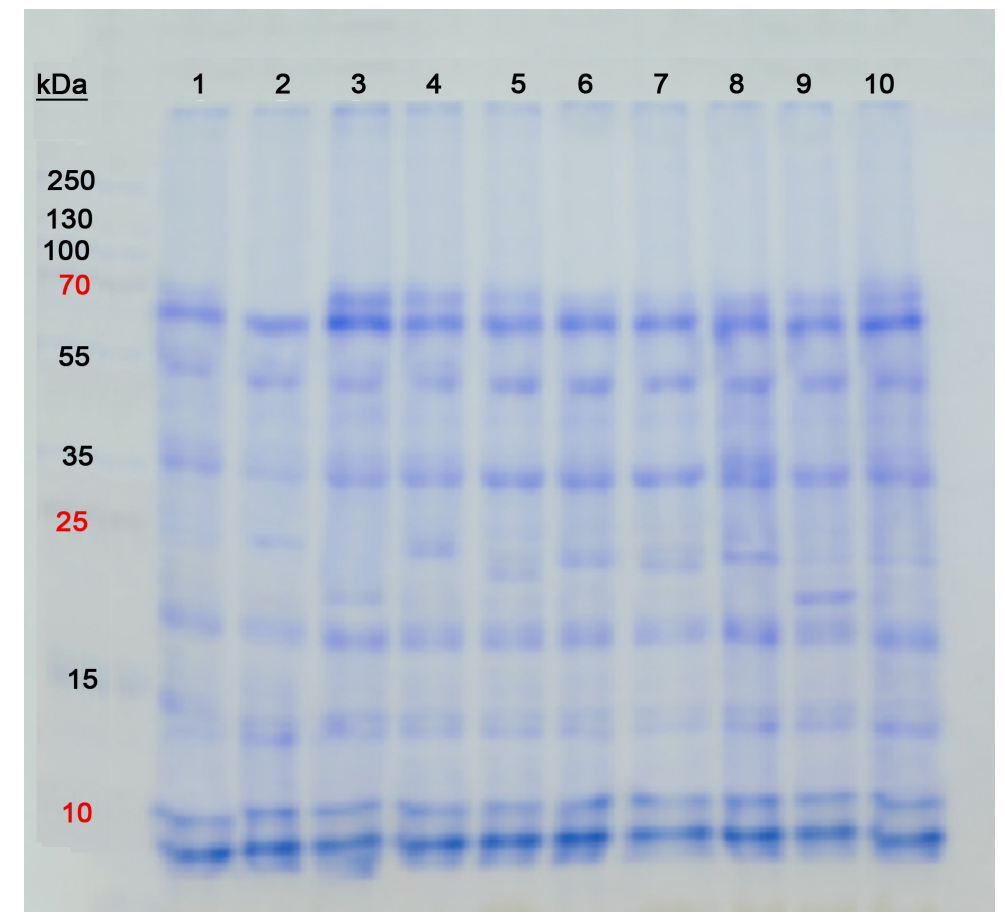

Figure 1. Electrophorogram showing banding patterns of globulin protein fractions from selected varieties of Ethiopian durum wheat. Lanes 1, Werer; 2, Yerer; 3, Asasa; 4, Hitosa; 5, Candate-utuba; 6, Ude 7, Foka; 8, Denbi; 9 , Mangudo; 10, Bichena, respectively.

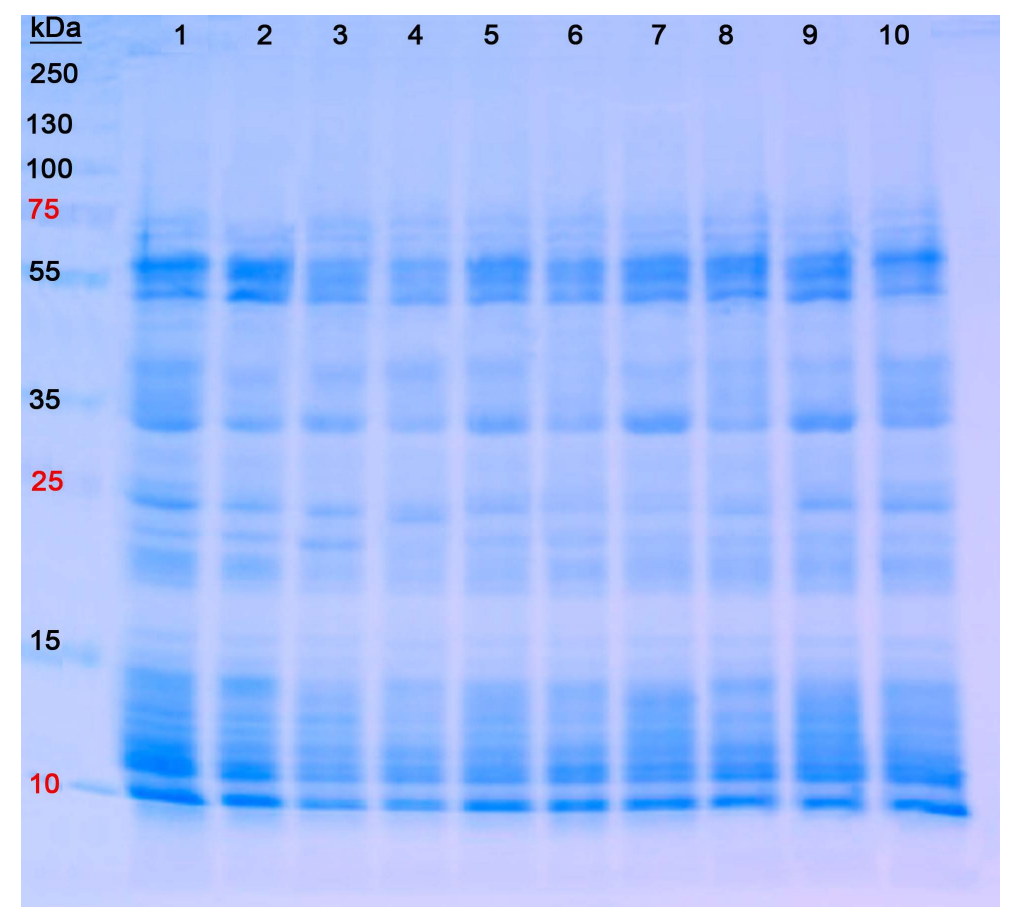

Figure 2. Electrophorogram showing banding patterns of albumin protein fractions from selected varieties of Ethiopian durum wheat. Lanes 1, Werer; lane 2, Yerer; lane 3, Asasa; lane 4, Hitosa; lane 5, Candate-utuba; lane 6, Ude lane 7, Foka; lane 8, Denbi; lane 9, Mangudo; lane 10, Bichena, respectively. 


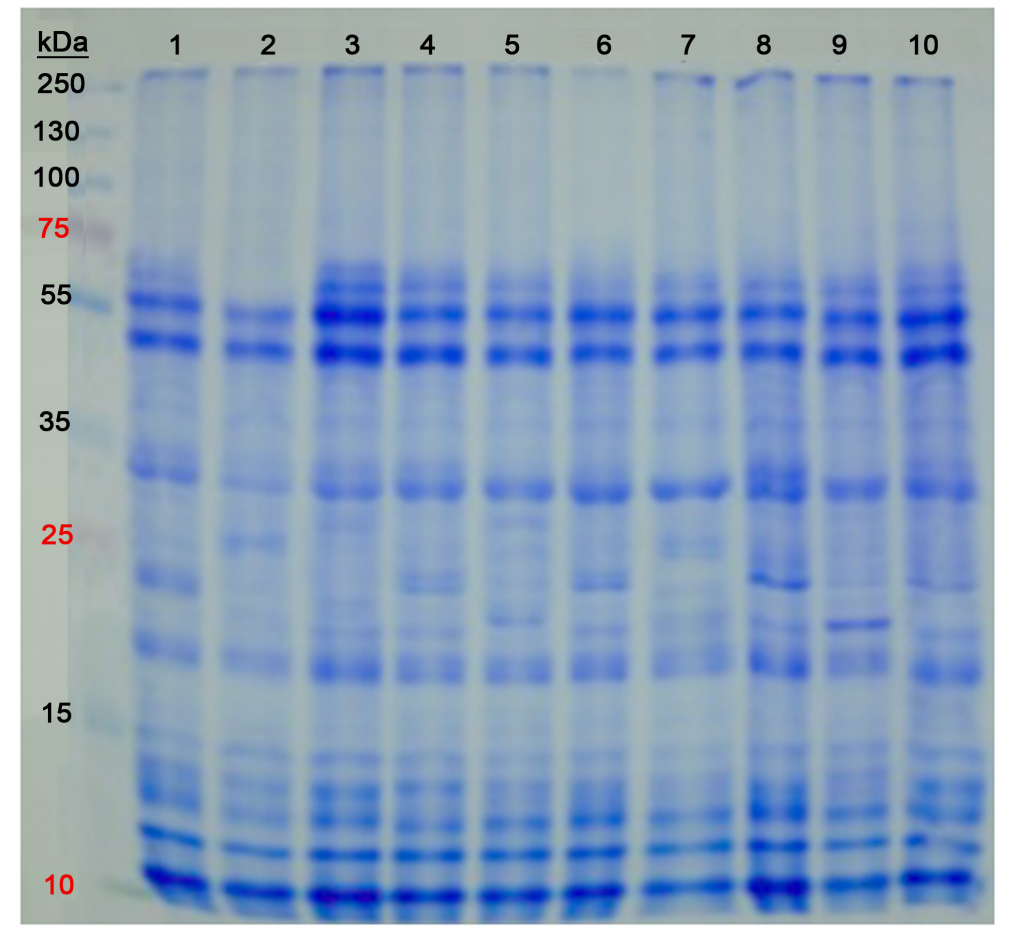

Figure 3. Electrophorogram showing banding patterns of albumin-globulin protein mixtures from selected varieties of Ethiopian durum wheat. Lanes 1, Werer; lane 2, Yerer; lane 3, Asasa; lane 4, Hitosa; lane 5, Candate-utuba; lane 6, Ude lane 7, Foka; lane 8, Denbi; lane 9, Mangudo; lane 10, Bichena, respectively.

globulins could also be used as suitable and useful genetic markers to discriminate genotypes.

A major cause of polymorphismin any specific protein is known to be related with gene silencing [23].

The gel electrophoresis result of albumin proteins did not show any significant variation among the genotypes. Almost all bands were monomorphic across all wheat genotypes. Molecular weight of the polypeptides ranged from 10 to 65 $\mathrm{kDa}$ and the number and position of bands were similar for all varieties (Figure 2). Generally, around 20 different polypeptides were detected in the albumin fraction. Likewise, the number of bands in globulin proteins was from 10 to 16 . This is in agreement with other previous research findings [3].

The heterogeneity of albumin and globulin was also revealed by the banding patterns of the mixture of globulin and albumin fractions (Figure 3 ). The varietal heterogeneity of these fractions was more similar to that detected by globulin fractions. Diversity of albumin and globulin proteins in wheat varieties was demonstrated in the earlier research works [24]. This pioneering research on albumins has reported the presence of three protein components in the water soluble proteins. Following this finding, there were some contradicting reports on the presence of noted molecular weight heterogeneity in both in the water-soluble and salt-soluble proteins. 


\subsection{Genetic Relationship among Varieties}

The dendrogram constructed based on the electrophoretic data of globulin protein fractions of the 20 durum wheat varieties is shown in Figure 4. There was fairly clear separation of the varieties. The cluster analysis result of globulin proteins classified the durum wheat varieties into three major lineage groups at a cutoff value 2.5. The varieties in cluster 3 were composed of widely adapted types, whereas the varieties in cluster 1 and cluster 2 were primarily from highland areas.

\section{Conclusion}

The present finding has revealed fairly significant polymorphism in the globulin protein fractions. Variability was observed in the bands corresponding to molecular weights from 15 to $35 \mathrm{kDa}$. Contrary to this, albumin proteins did not show any significant variation among genotypes. Generally, apart from the gliadins and glutenins, the globulin has also a potential to serve as biochemical markers for evaluation of polymorphism and genetic diversity in durum wheat varieties. Use of globulin polymorphism in diversity studies could facilitate efforts to improve the quantity and quality of durum wheat varieties and could influence the selection of better raw materials for improved agronomic traits.

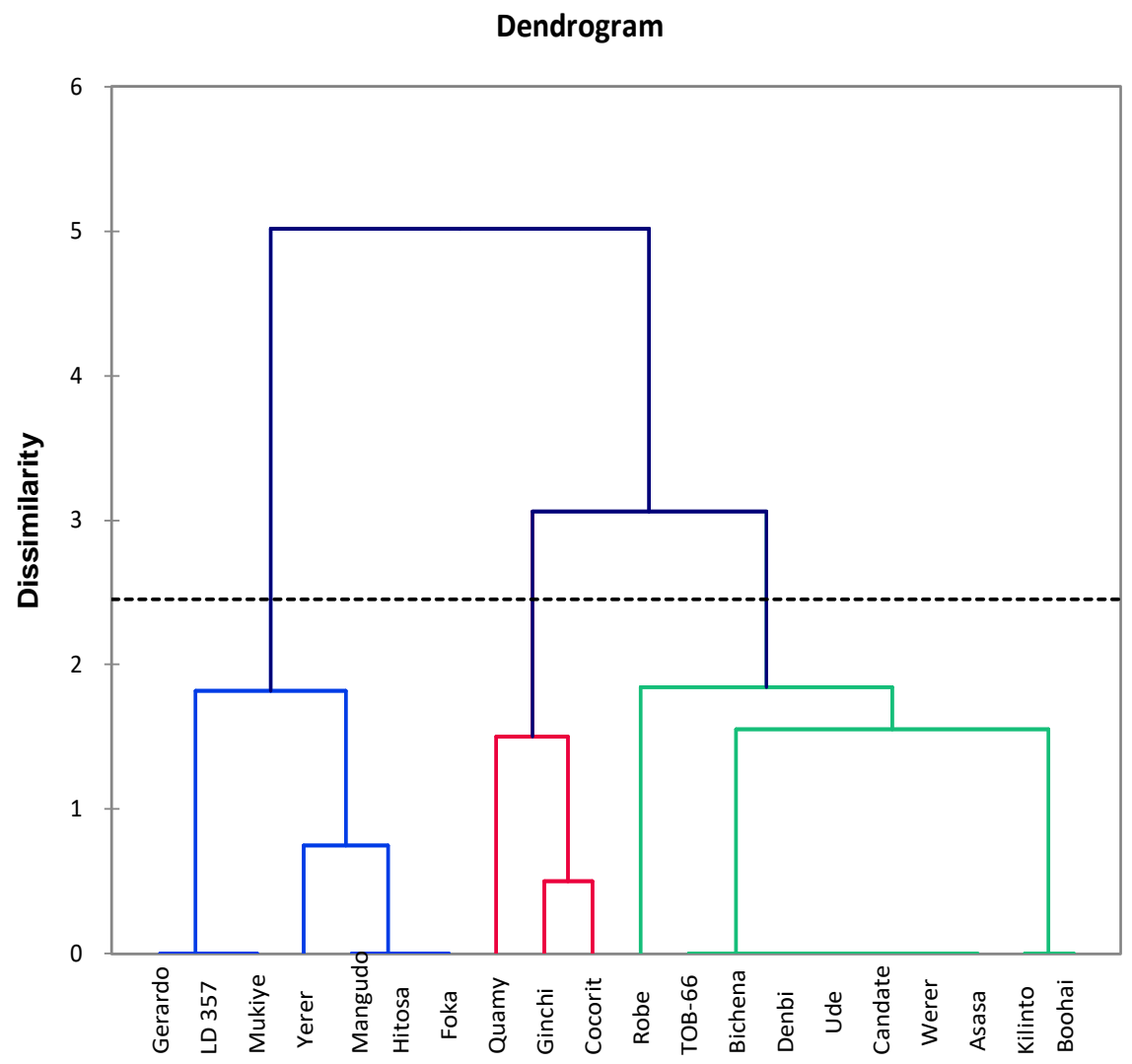

Figure 4. Dendrogram constructed based on the electrophoretic data of globulin protein fractions of the 20 durum wheat varieties. 


\section{Conflicts of Interest}

The authors declare no conflicts of interest regarding the publication of this paper.

\section{References}

[1] Harsch, S., Günter, T., Kling, C.I. and Rozynek, B. (1997) Characterization of Spelt (Triticum spelta L.) Forms by Gel-Electrophoretic Analyses of Seed Storage Proteins. I. The Gliadins. Theoretical and Applied Genetics, 94, 52-60. https://doi.org/10.1007/s001220050381

[2] Merlino, M., Leroy, P., Chambon, C. and Branland, G. (2009) Mapping and Proteomic Analysis of Albumin and Globulin Proteins in Wheat Kernels. Theoretical and Applied Genetics, 18, 1321-1337. https://doi.org/10.1007/s00122-009-0983-8

[3] Zilic, S., Barac, M., Pesic, M., Hadzi-TaskovicSukalovic, V., Dodig, D., Mladenovic Drinic, S. and Jankovic, M. (2011) Genetic Variability of Albumin-Globulin Content, and Lipoxygenase, Peroxidase Activities among Bread and Durum Wheat Genotypes. Genetika, 43, 503-516. https://doi.org/10.2298/GENSR1103503Z

[4] Belderok, B., Mesdag, J. and Donner, D.A. (2000) Bread-Making Quality of Wheat: A Century of Breeding in Europe. Kluwer Academic Publisher, Dordrecht. https://doi.org/10.1007/978-94-017-0950-7

[5] Dupont, F.M. and Altenbach, S.B. (2003) Molecular and Biochemical Impacts of Environmental Factors on Wheat Grain Development and Protein Synthesis. Journal of Cereal Science, 38, 133-146. https://doi.org/10.1016/S0733-5210(03)00030-4

[6] Morris, C.F. (2002) Puroindolines: The Molecular Genetic Basis of Wheat Grain Hardness. Plant Molecular Biology, 48, 633-647. https://doi.org/10.1023/A:1014837431178

[7] Kodama, T., Miyazaki, T., Kitamura, I., Suzuki, Y., Namba, Y., Sakurai, J., Torikai, Y. and Inoue, S. (2005) Effects of Single and Long-Term Administration of Wheat Albumin on Blood Glucose Control: Randomized Controlled Clinical Trials. European Journal of Clinical Nutrition, 59, 384-392. https://doi.org/10.1038/sj.ejcn.1602085

[8] Dong, K., Ge, P., Ma, C., Wang, K., Yan, X., Gao, L., Li, X., Liu, J., Ma, W. and Yan, Y. (2012) Albumin and Globulin Dynamics during Grain Development of Elite Chinese Wheat Cultivar Xiaoyan 6. Journal of Cereal Science, 56, 615-622. https://doi.org/10.1016/j.jcs.2012.08.016

[9] Yadav, D. and Singh, N.K. (2011) Wheat Triticin: A Potential Target for Nutrition Quality Improvement. Asian Journal of Biotechnology, 3, 1-21.

https://doi.org/10.3923/ajbkr.2011.1.21

[10] Lasztity, R. (1984) The Chemistry of Cereal Proteins. 2nd Edition, Taylor \& Francis, Oxon.

[11] , R., Ahmad, F., Alsaleh, A., Labhane, N., Ozkan, H., Chung, G. and Baloch, F.S. (2017) DNA Molecular Markers in Plant Breeding: Current Status and Recent Adv Nadeem, M.A., Nawaz, M.A., Shahid, M.Q., Dogan, Y., Comertpay, G., Yıldız, M., Hatipoglu ancements in Genomic Selection and Genome Editing. Biotechnology \& Biotechnological Equipment, 32, 261-285. https://doi.org/10.1080/13102818.2017.1400401

[12] Osborne, T.B. (1907) The Proteins of the Wheat Kernel. Carnegie Institution of Washington, Publication No. 84, Judd \& Detweiler, Inc., Washington DC. https://doi.org/10.5962/bhl.title.26152 
[13] Jemanesh, K. (2013) Crop Variety Register Issue 1-12.

[14] Laemmli, U.K. (1970) Cleavage of Structural Proteins during the Assembly of the Head of Bacteriophage T4. Nature, 227, 680-685. https://doi.org/10.1038/227680a0

[15] Axford, D.W.E., McDermott, E.E. and Redman, D.G. (1979) Note on the Sodium Dodecyl Sulphate Test of Bread-Making Quality: Comparison with Pelshenke and Zeleny Tests. Cereal Chemistry, 56, 582.

[16] SAS (1991) Statistical Analysis System Institute-SAS/STAT Procedure Guide for Personal Computers. Version 5, SAS Inst., Cary.

[17] Gafurova, D.A., Tursunkhodzhaev, P.M., Kasymova, T.D. and Yuldashev, P.K. (2002) Fractional and Amino-Acid Composition of Wheat Grain Cultivated in Uzbekistan. Chemistry of Natural Compounds, 38, 462-465.

[18] Tadesse, D., Labuschagne, M.T. and van Deventer, C.S. (2006) Quality of Ethiopian Durum Wheat Lines in Two Diverse Environments. Journal of Agronomy and Crop Science, 192, 147-150. https://doi.org/10.1111/j.1439-037X.2006.00190.x

[19] Dodig, D., Zoric, M., Knezevic, D., Dimitrijevic, B.G. and Momirovic, S. (2007) Assessing Wheat Performance Using Environmental Information. Genetika, 39, 413-425. https://doi.org/10.2298/GENSR0703413D

[20] Woyema, A., Bultosa, G. and Taa, A. (2012) Effect of Different Nitrogen Fertilizer Rates on Yield and Yield Related Traits for Seven Durum Wheat (Triticum turgidum L. var Durum) Cultivars Grown at Sinana, South Eastern Ethiopia. African Journal of Food, Agriculture, Nutrition \& Development, 12, 6079.

[21] Stehno, Z., Konvalina, P. and Dotlacil, L. (2008) Emmer Wheat Growing. Praha, VÚRV, 22.

[22] Hassan, H.M.M., Afify, A.S., Basyiony, A.E. and Ahmed, G.T. (2010) Nutritional and Functional Properties of Defatted Wheat Protein Isolates. Australian Journal of Basic and Applied Sciences, 4, 348-358.

[23] Lawrence, G.J. and Shepherd, K.W. (1980) Variation in Glutenin Protein Subunits of Wheat. Australian Journal of Biological Sciences, 33, 221-233. https://doi.org/10.1071/BI9800221

[24] Laws, W.D. and France, W.G. (1948) A Comparative Study of Some Protein Fractions of Wheat Flour. Cereal Chemistry, 25, 231-243. 